\title{
Monitoring as the Key Factor for Sustainable Use and Protection of Groundwater in Karst Environments-An Overview
}

\author{
Zoran Stevanović $^{1, *(\mathbb{D}) \text { and Aleksandra Maran Stevanović }}{ }^{2}$ (D) \\ 1 Centre for Karst Hydrogeology, Department of Hydrogeology, Faculty of Mining \& Geology, \\ University of Belgrade, 11000 Belgrade, Serbia \\ 2 Museum of Natural History, 11000 Belgrade, Serbia; amaran@nhmbeo.rs \\ * Correspondence: zstev_2000@yahoo.co.uk; Tel.: +381-60-5291956
}

check for updates

Citation: Stevanović, Z.; Stevanović, A.M. Monitoring as the Key Factor for Sustainable Use and Protection of Groundwater in Karst Environments -An Overview. Sustainability 2021, 13, 5468. https://doi.org/10.3390/ su13105468

Academic Editor: Zoran Nakić

Received: 8 April 2021

Accepted: 5 May 2021

Published: 13 May 2021

Publisher's Note: MDPI stays neutral with regard to jurisdictional claims in published maps and institutional affiliations.

Copyright: (c) 2021 by the authors. Licensee MDPI, Basel, Switzerland. This article is an open access article distributed under the terms and conditions of the Creative Commons Attribution (CC BY) license (https:// creativecommons.org/licenses/by/ $4.0 /)$.

\begin{abstract}
As a specific type of landscape and aquifer, karst is developed in soluble carbonate and evaporitic rocks and is of great importance for humanity. It covers more than $15 \%$ of Earth's ice-free land and its aquifers provide about $10 \%$ of the world population's drinking water. However, in general, its importance is not adequately supported by monitoring. Due to very dynamic karst regimes, in many countries, monitoring networks and their technology must be enlarged and improved, in terms of both the quantity and quality of water. The article discusses the current state of monitoring in legislation and water practice, as well as its importance in preventing water pollution, ensuring water provision to dependent ecosystems and preparing adaptation strategies to mitigate the negative effects of climate changes. Karst aquifers' heterogeneity, high vulnerability to pollution and their very dynamic regimes require a more frequent observation of discharge and water quality parameters than any other aquifer system. There is also a need for installing sophisticated monitoring equipment, which enables remote observation of changes in dynamic karst systems. Improving monitoring and creating an early warning system would have a direct and positive effect on water management and might also be able to prevent uncontrolled groundwater extraction and deterioration of water quality.
\end{abstract}

Keywords: karst aquifer; groundwater regime; frequent monitoring; sustainability

\section{Introduction}

At the global level, karst aquifers are the second-ranked groundwater source used for potable water supply. The first place is reserved for intergranular aquifers-alluvial i.e., linked to major rivers, or coastal i.e., extended over sea or lake shorelines [1,2]. Soluble and karstified carbonate or evaporitic rocks cover some $15 \%$ of the continents' ice-free land [3] and provide drinking water to about $10 \%$ of the world's population [4]. Of all the aquifer systems, karst aquifers are characterised by the most dynamic regime: the water table fluctuates and the springs' discharge or water chemistry can vary from one day or hour to the next [5-7]. High groundwater velocity has been confirmed by numerous tracing experiments conducted in many karst regions [8,9]. It is caused by high porosity and well-developed channels in karstified rocks. Such hydrogeological settings are the reason why karst aquifers are characterised by a low attenuation capacity and are highly vulnerable to pollution. Many methods have been developed in water practice to assess their intrinsic vulnerability. Methods such as DRASTIC [10] or EPIK [11] are just some of those that are applied the most in water management practice.

Is this dynamic water regime adequately supported by monitoring? The answer is that there is a small number of countries, mostly in the developed world, that conduct a thorough observation of springs and wells linked to karst aquifers. This article is an attempt to provide an assessment of the current situation at the global level, as well as in some selected "karst" countries, and to present possible solutions to improve knowledge of the regime of this precious water resource. 


\section{Methods}

The evaluation of legislative acts and global initiatives that concern monitoring should be the first step of the analysis. The evaluation includes the UNESCO's International Hydrological Programme (IHP) and the Law on Transboundary Aquifers [12]. Furthermore, there is the UN-IGRAC initiative to establish a global groundwater monitoring network, which is mostly focused on developing countries in Africa and Asia.

Aiming to establish a common environmental policy in its Member States, the European Union (EU) has adopted a set of directives concerning water, air, climate change and agriculture. The crucial document is the Water Framework Directive (WFD) [13], which establishes a comprehensive, cross-border approach to water protection with the aim of achieving a good status for European water bodies. The Groundwater Directive imposed by EU in 2006 [14] and guides for WFD implementation, particularly nos. 7 [15] and 15 [16], are also important for the regulation of monitoring activities in the EU.

Another step applied in this analysis is the evaluation of the current practice of groundwater monitoring, and that of karst waters in particular. Such an evaluation starts at the global level and then focuses on examples from selected regions and countries where karst is widely exposed at the land surface, and where karst aquifers are utilised.

Some of the previous global-scale projects, such as WOKAM, implemented by Goldscheider et al. [3], showed the distribution and provided a map of karst aquifers, while some new studies such as the WOKAS of Olarinoye et al. [17] have initiated the creation of a global base of karst springs and collection of data on their discharges.

Southeast Europe, including the Dinaric region, is commonly considered as "classical karst" and the place of birth of karstology as a scientific discipline [18]. Evaluation of the actual monitoring includes several core countries of that region.

The establishment of a national or regional monitoring network has been proposed or implemented in several countries located in the arid regions of Asia and Africa, under internationally funded projects, and experiences thus gained could be important for similar actions in the future.

Monitoring of karst aquifers' behaviour is an essential part of many practical projects for groundwater use or control. The applied methods of monitoring are different: from monitoring that is conducted sporadically and using manual measurements, to those that are continuous and fully automated. Several case studies have been evaluated to illustrate the advantages of monitoring for such projects' success.

There are several published papers or manuals that put procedures for monitoring karst waters in direct focus. Their findings and proposals towards better understanding of karst waters' regime were also useful for this analysis.

The above studies and their data provide an opportunity for a comprehensive overview of the actual status and the proposal for optimal monitoring, which should enable more sustainable use and preventive protection of karst waters.

\section{Results-Monitoring}

\subsection{Global Initiatives and Projects}

UNESCO-IHP was established in 1975 as the only intergovernmental programme of the United Nations system devoted to water research and management, and to related education and capacity development [19]. Since then, it has supported international cooperation in hydrological and freshwater sciences and facilitated an interdisciplinary and integrated approach to watershed and aquifer management. Although none of the five focal areas imposed for groundwater management explicitly identifies monitoring, it is closely attributed to some of them. For instance, Enhancing sustainable groundwater resources management or Adapting to the impacts of climate change on aquifer systems is impossible to implement without adequate datasets on groundwater regime.

In December 2008, the UN General Assembly (UNGA) adopted the Resolution (A/RES/63/124) 1 on the "Law of Transboundary Aquifers" prepared by the International Law Commission. Article 13 of the Law is dedicated to monitoring and prescribing 
the obligation for Aquifer States to monitor their transboundary aquifers or aquifer systems [12] (p. 7). “They shall, wherever possible, carry out these monitoring activities jointly with other aquifer States concerned and, where appropriate, in collaboration with competent international organizations. Where monitoring activities cannot be carried out jointly, the Aquifer States shall exchange the monitored data among themselves."

The International Groundwater Resources Assessment Centre (IGRAC) is a UNESCO centre specialised for regional- and transboundary-level assessment and monitoring of groundwater resources [20]. Recognising the importance of monitoring as the basis for the assessment of quantity and quality of groundwater for effective groundwater management on one side, and the lack of such of information at the regional and global scales on the other, IGRAC took initiative in 2008 and coordinated the preparation of the Guideline on Groundwater Monitoring for General Reference Purposes [21] and established the Global Groundwater Monitoring Network (GGMN) in 2012.

GGMN is a participative, web-based network set up to improve the quality and accessibility of groundwater monitoring information and knowledge of the state of groundwater resources [20]. The GGMN Portal [20] contains locations of the monitoring sites on all five continents, and their data can be displayed showing the mean, range or change in the groundwater level for the selected time period.

IGRAC also created a global overview of the quantitative groundwater monitoring networks, which includes 108 countries [22]. Although not all of them provide complete data, this report is a very useful source of information on how actual monitoring of groundwater level or springs' discharge is organised.

The Water Framework Directive (WFD) [13-16] introduces two types of monitoringsurveillance and operational, depending on the nature of groundwater pressures. Operational monitoring requires a higher monitoring frequency and surveying of specific components critical to water quality. Monitoring points are not necessarily required in all delineated groundwater bodies (GWB), but they must be located in a way that makes them representative of all groundwater bodies within a river basin district.

In terms of quantitative assessment, the distribution of monitoring points must ensure that spatial and temporal variability of the groundwater surface can be sufficiently well recorded within a groundwater body. Pumped wells are not normally suitable for use as water level monitoring points. In the WFD, the groundwater level is the main parameter that defines the quantitative status. There is no exact limit, but it needs to ensure that long-term use will not threaten the available groundwater resource, that the environmental objectives of associated surface water bodies will be achieved, and that there will be no threat to terrestrial ecosystems.

The GWB shall be monitored for the following minimum set of parameters in all cases (core parameters):

1. Temperature (T);

2. Oxygen content (DO);

3. $\mathrm{pH}$ value $(\mathrm{pH})$;

4. Electrical Conductivity (EC);

5. Nitrate $\left(\mathrm{NO}_{3}\right)$;

6. Ammonium $\left(\mathrm{NH}_{3}\right)$.

The GWBs that have been identified as being at significant risk of failing to meet the objectives shall be monitored for those parameters which are indicative of the risk. In the case of transboundary groundwater bodies, they shall be monitored for parameters and potential pollutants found in the area which are relevant for the protection of all of the uses supported by the groundwater flow [23].

The WFD and the Common Implementation Strategy (CIS) guidelines propose the minimum frequency of observation, which includes karst (flow) among others aquifer systems (flows). For surveillance monitoring, where the understanding of aquifer systems is inadequate, in the case of a karst aquifer a quarterly observation of core and additional parameters is proposed in the initial stage, while monitoring of the long-term 
frequency of core parameters should be carried out twice per year. When it comes to operational monitoring and higher vulnerability of karst aquifers under continuous pressure, they require quarterly monitoring, while in the case of less vulnerable aquifers under seasonal/intermittent pressure, the guideline leaves the decision to the monitoring operator-i.e., "as appropriate" [13-16].

Information collected on the groundwater regime is reported annually to Eionet, a partnership network of the European Environment Agency (EEA) and its 39 members and cooperating countries.

\subsection{Organised Groundwater Monitoring Practice in Certain Regions and Countries with a Large Extension of Karst}

Groundwater is systematically monitored in many countries or regions, by measuring groundwater table in drilled piezometers or pumped wells, groundwater abstraction rates, springs' discharge and selected parameters of groundwater quality. In contrast, in many countries where groundwater is essential or even sole water resource there is a lack of monitoring or it is implemented only as project-based.

For the overview of the functionality of national monitoring systems, we randomly selected a few countries with considerable karst extension, USA with $21.3 \%$ or around $2.0 \times 10^{6} \mathrm{~km}^{2}$ of its territory covered by karst [3] and few smaller countries from Alpine orogenic belt with dominant presence of karst [4,18].

National Water Information System (NWIS) of the United States Geological Survey (USGS) contains water-resources data from approximately 1.5 million sites in all 50 states. Groundwater data, such as water level, are collected at wells and springs. Water-quality data are available for both surface water and groundwater. Examples of water-quality data collected are: T, EC, pH, nutrients, pesticides and volatile organic compounds. Out of the total number of 14,377 sites observed for groundwater level and 3858 sites observed for water quality, the USGS website [24] presents current (1) and historical (2) data: (1) current conditions at selected 1670 groundwater sites based on most recent data from on-site automated recording equipment. Measurements are commonly recorded at a fixed interval of 15 to $60 \mathrm{~min}$ and transmitted to the USGS every hour; (2) historical observations are shown from 4724 sites. As for other non-automatic stations, although frequency of observation does not consider karst aquifers to be "special cases", many such large aquifers are observed on a daily basis (e.g., Floridian).

In the region of Southeast Europe, karst water is mostly utilised for potable water supply, but also for hydro-energy production. Austria is an example of a country that bases almost $100 \%$ of its municipal water supply on groundwater, to which karst aquifers' water contributes with almost 50\% [25]. According to the Yearbook 2016, the Groundwater Network of the Hydrological service [22,26] includes 3535 groundwater level measuring points, 1518 groundwater temperature measuring points, and 91 springs issuing mostly from karst aquifers. Groundwater levels are collected either weekly (41\% of the measuring sites) or continuously, together with water temperature, by data loggers, and transmitted in $15 \mathrm{~min}$ to $1 \mathrm{~h}$ intervals. The parameters collected at springs (water level/discharge, $\mathrm{T}$, EC) are also measured every $15 \mathrm{~min}$.

In the Dinaric Region, despite the fact that karst aquifers are widely distributed and utilised, there are enormous differences between the countries in terms of organisation of monitoring. The best monitoring has been noted in Slovenia and Croatia.

In Slovenia, the national groundwater monitoring network is under the responsibility of the Slovenian Environment Agency. In the year 2017, a total of 27 observation points were located at springs, or at streams in head watershed, in the proximity of springs. These sites represent the regime of nine GWBs [27]. The number of observation points for monitoring groundwater quantity and quality of other aquifers is higher, including more than 150 objects.

As the responsible agency in Croatia, Croatian Waters provides and controls groundwater monitoring at delineated GWBs. Information arrives from two sources, the Croatian Meteorological and Hydrological Service and the Institute of Public Health. In karstic 
terrains of Croatia there are 18 karstic GWBs, 13 in the Adriatic Basin and 5 in the Black Sea basin. Some 48 observation points (dominantly springs including those that are tapped, or streams in the vicinity of the spring sites) are included in the quantitative monitoring of karstic GWBs and the majority of observation stations are automated [28]. The observation of all springs that discharge a minimum of more than $501 / \mathrm{s}$ has been proposed, but not yet fully implemented.

In Serbia, more than 400 operational groundwater points are observed and maintained by the Hydrometeorological Service, but this covers only 31 GWBs or $20 \%$ of the total of the number of delineated ones. Most of them are located in alluvia of large rivers, and just five are located in karst aquifers [29].

A similar situation, with a very limited number of water sites in karst aquifers monitored by national institutions despite their wide extension, can be found in Bosnia and Herzegovina, Montenegro as well as Albania. However, some of these countries' recently prepared River Basin Management Plans envisage the expansion of the groundwater monitoring network.

Apart from the observation of the groundwater regime within national groundwater networks, most sources of potable water are regularly controlled by the laboratories of waterworks in charge, or by institutions responsible for health and sanitation control.

In several cases, a regional/local network was established as part of a funded project supported by an external party (national or international organisations, international banks, scientific funds or donor programmes). There are numerous examples of established networks, but it is also true that many of them stopped working or the observation frequency has been reduced once the responsibility for the operation and maintenance was transferred from donors to national or local authorities.

A large monitoring programme was established by the FAO in Northern Iraq in 2000 2003, where clear indications of groundwater over-extraction from both inter-granular and karst aquifers was caused by several consecutive drought years [30]. At the last stage, the groundwater network included 180 deep wells and 150 springs that were monitored on a daily or weekly basis. The monitoring found that some springs had dried out for the first time in history, but that they have recovered their previous discharge rates after a wet season in 2002. Some other springs never again reached their previous yield rates, mostly due to numerous wells that were drilled around them [30]. Unfortunately, after the FAO programme ended, monitoring did not continue with the earlier intensity. It is worth mentioning that had the observation of the quality of groundwater from karst aquifers been performed continuously, certain hydric epidemics might have been prevented.

In Northern Somalia, FAO also established, under the SWALIM Programme, a groundwater network comprised of sources of eight major settlements, with an idea to expand the system to a total projected number of about 250 monitoring points [31].

\subsection{Monitoring in Water Utilities and Hydrogeological Research in Karst}

Monitoring of quantitative and qualitative parameters of karst aquifer is needed both for the pure "scientific" research, whose aim is to characterise and understand the functionality of a designated aquifer system, and for many diverse practical and engineering problems that require a technical solution. Most projects involve a combination of these two approaches, and they are both contributing to karst theory and practice. For a complex and heterogenous water-bearing medium such as karst, almost every case is different and specific [7,32], and not every lesson learned in one karst terrain can be adopted and applied in others.

In the practice of systematically organised monitoring, we can distinguish four categories of monitoring of the water level or discharge of karst springs and stream-flow:

1. Manually carried out;

2. Semi-automatic;

3. Fully automated;

4. Remotely organised. 
1. The first is a traditional one, but it is also the most complicated as it requires manpower to visit the site and measure the water table or establish gauge stations, to conduct hydrometry and to read the gauge. However, this method is applied in many parts of the world. Thanks to this classical method, we now have valuable discharge data on numerous springs around the world. For instance, the gauge station at the famous spring Fontaine de Vaucluse in southern France (Figure 1) was installed in 1878. We have had excellent records since then, which helped not only to understand the functionality of this karst system [33], but also to reconstruct the impact of climate variables on discharge [34]. Equally important is the observation of streams and rivers in karst basins. In many cases, such data helped explain the complex and close interaction of ground and surface waters in karst [35].

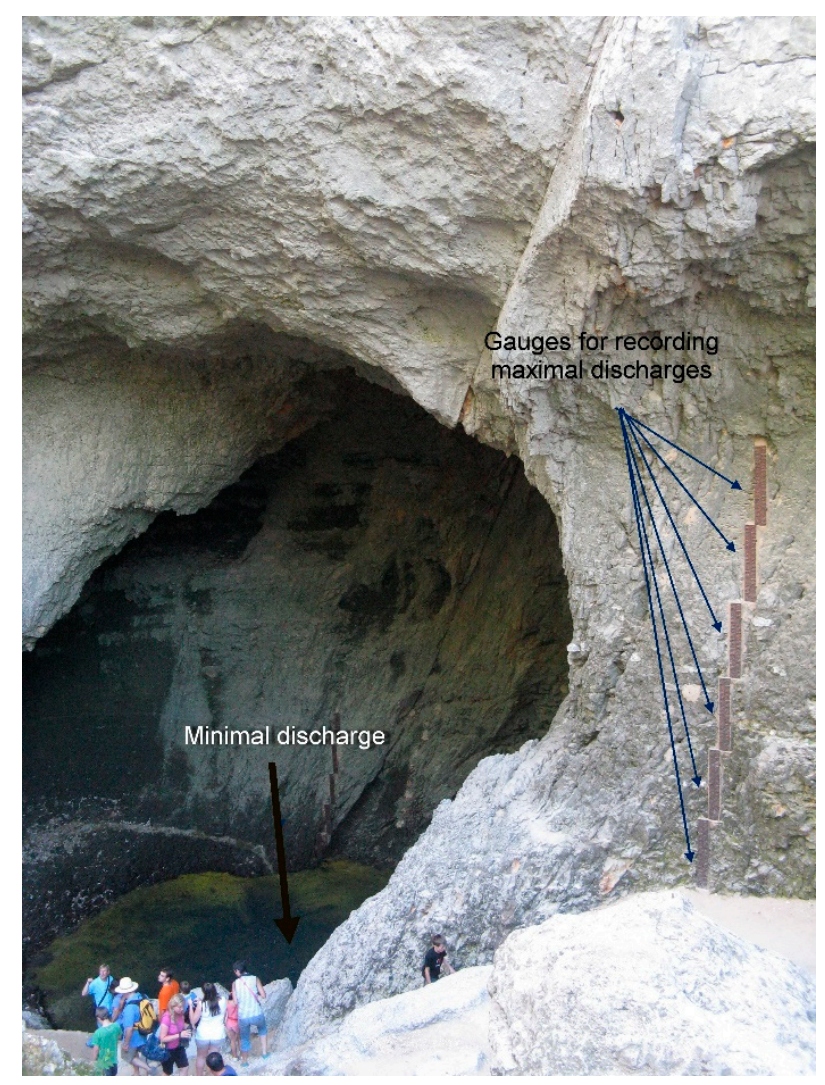

Figure 1. Fontain de Vaucluse karst spring in south France, one of the largest in Europe and in possession of longest data records.

2. Semi-automatic monitoring implies the installation of a limnigraph or data loggers, while data is collected at the desired recording interval and can be presented in charts or stored on a memory device, respectively. From time to time, these data can be transferred to modems or downloaded to laptops via USB port. Optic limnigraph measures the water level mechanically, by way of a float system (Figure 2). It is the oldest and most precise measurement method, while a modern submersible water level sensor ("diver") measures barometric pressure i.e., the thickness of water column and recalculates obtained values to the water level altitude or discharge, if geometry of the section is known (Figure 3). A modern data logger can store more than 50,000 measurement data, while the recording interval can be fixed at the desired frequency. 


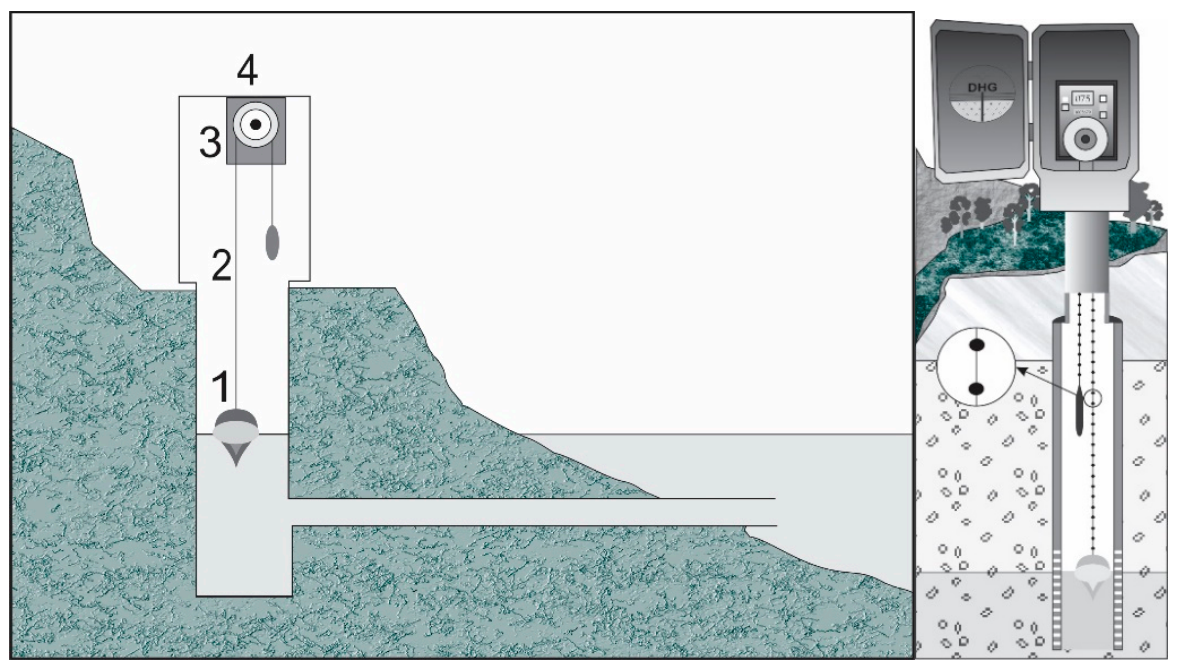

Figure 2. Limnigraph with a float system. "Classical" mechanical instrument which is still widely used globally.

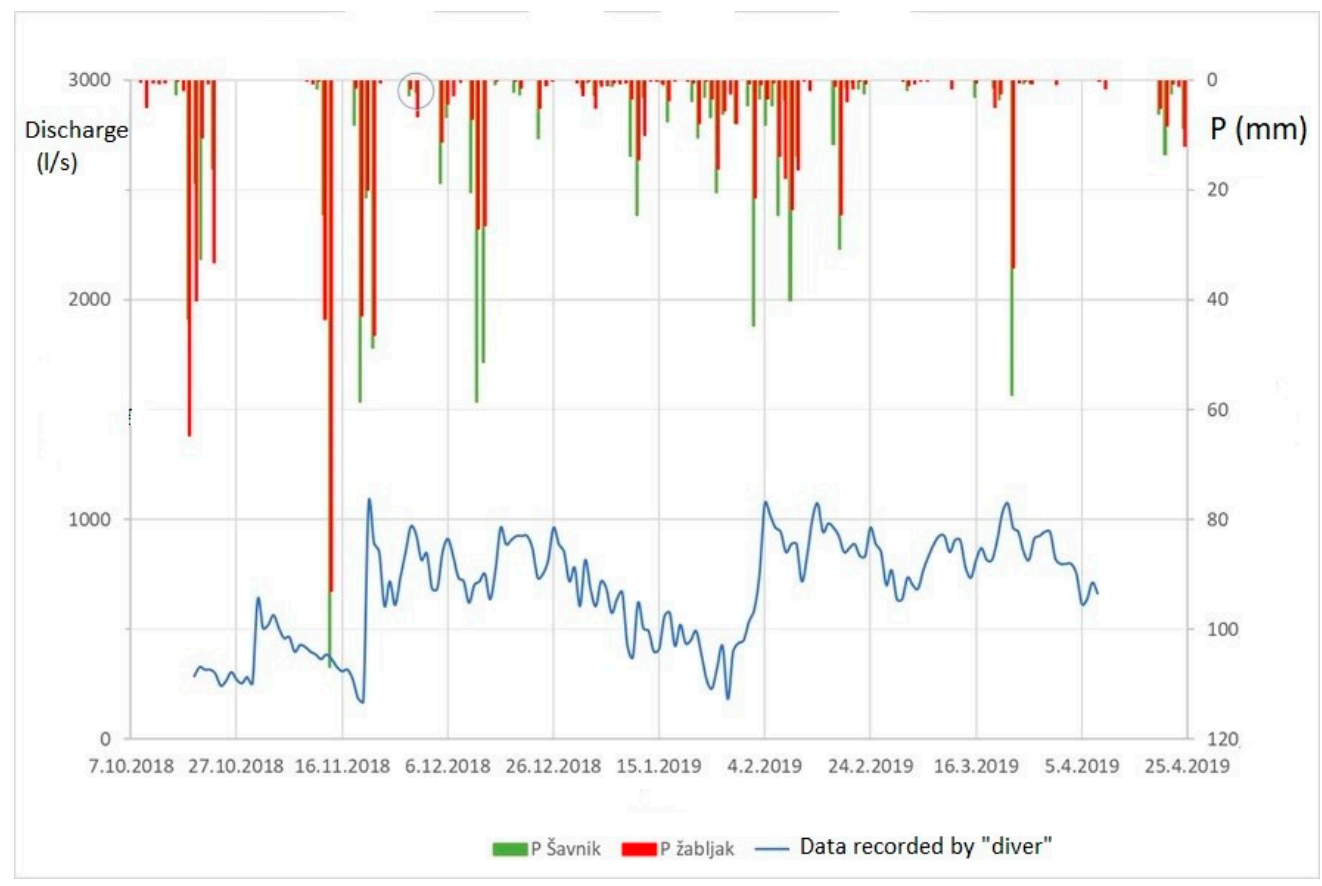

Figure 3. Correlation diagram of rainfall and karst spring hydrograph obtained by continued measurement, by use of a "diver" data logger.

3. While semi-automatic monitoring implies a visit to the site from time to time, and data collection in situ, the fully automated process involves similar instruments. However, data transfer from the site to the computer system takes place in the office, via data transmitter and satellite signal (Figure 4).

4. Remote monitoring by means of satellite data interpretation cannot be as reliable as in situ measuring, but satellite-based GRACE measurements (of the Earth's gravity) over large regions have become an alternative approach in recent years [36]. GRACE observations have the potential to extend estimates of groundwater storage over time, although only as far back as 2002, when GRACE satellites were launched. Further application of satellite observations for the estimation of the recharge component via soil-moisture dynamics has been discussed by Hartmann et al. [37]. Using a remote soil-moisture moni- 
toring programme and the global database of karst spring discharges [17] enables creation and simulations at a preliminary global recharge model.

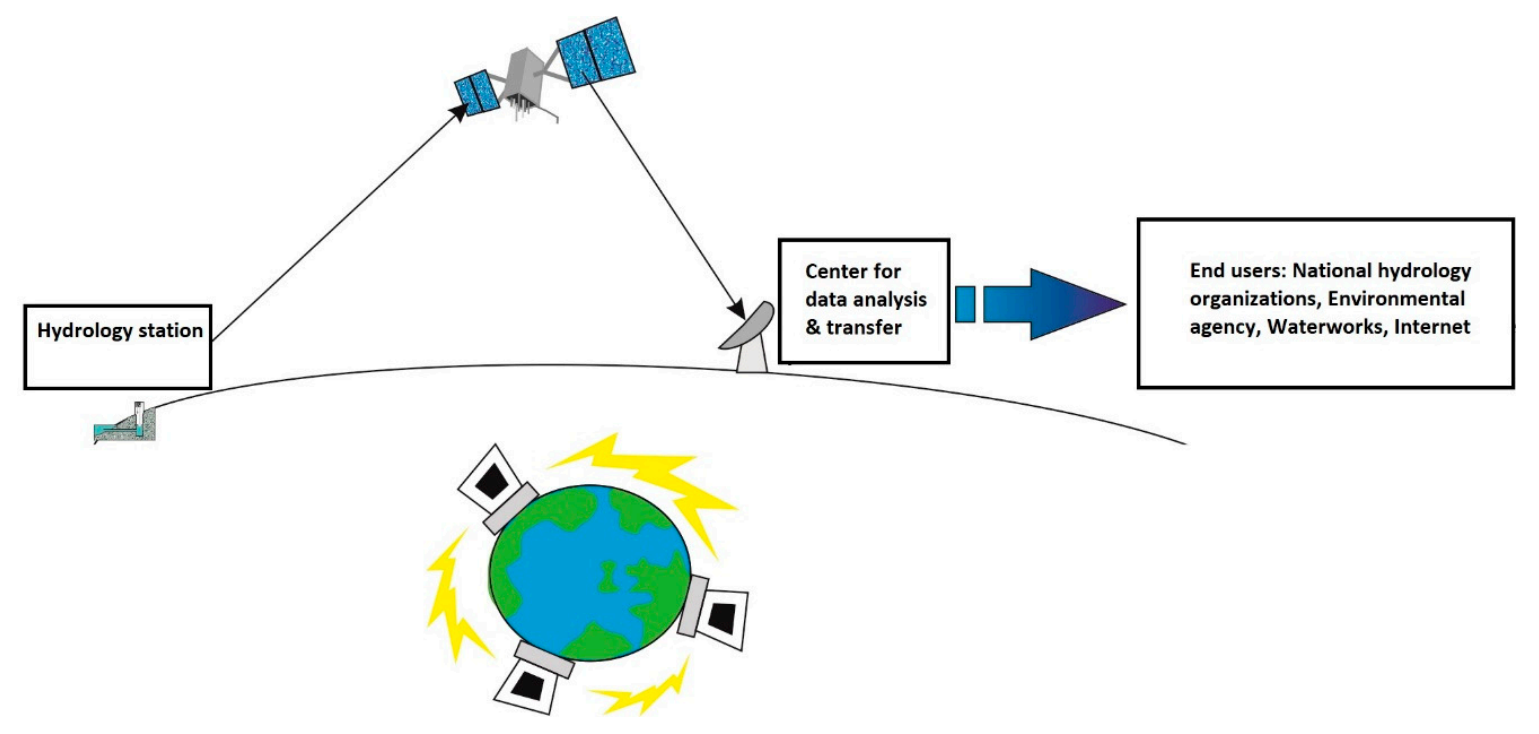

Figure 4. Data transmission from a hydrology station via satellite.

Monitoring of parameters of water quality can be performed the same way as the monitoring of water level/discharge under items 2 and 3 above, but it is still challenging when it comes to the process of automation. Nowadays, most data logger devices can measure electro-conductivity (EC), water temperature $(\mathrm{T})$ and $\mathrm{pH}$ values, while classical sampling and analysing water in a laboratory is still necessary for most micro-constituents.

Monitoring equipment is regularly installed at larger springs as well as those that are tapped for centralised water supply. Equipment comprises various instruments for measuring the flow, but also the physical or chemical parameters of tapped water. Turbidity, T, pH and EC are most often observed. Modern technologies enable the installation of different probes in collection points or in reservoirs, as well as automatic recording. Larger intake structures are overseen from a manipulation (operations) room. The system can include a very sophisticated computerised operations such as controlling the yield, observing the water quality or treating raw water. Many large water utilities are implementing technology that is commonly referred to as SCADA (Supervisory Control and Data Acquisition). Collecting monitoring data is particularly important for water management and planning future exploitation [38].

In the last decade, there have been several projects and activities that were aimed at developing the so-called Early Warning System (EWS), which would indicate the arrival of poor-quality water (especially during and after flood events), prevent further deterioration and stop water distribution to consumers until appropriate treatment measures have been taken or pollution has gone. Apart from water utilities, which in this way can prevent the pollution of their sources, systematic observation of karstic springs in remote mountain areas provides an insight into the natural water quality or presence of bacteria and other pathogens originating from decayed vegetation, livestock manure, farming and rare cottages. The EWS indicators such as turbidity, particle size distribution or total organic content could be observed separately or together, depending on the instruments. As such, some instruments can measure enzymatic activity, or particle sizes, whereas in certain others the UV light can measure intrinsic fluorescence, which indicates the presence of bacteria or dissolved organic matter [39]. For instance, the Spectral Absorption Coefficient (SAC $254 \mathrm{~nm}$ ) is a total parameter that measures dissolved organic material that absorbs UV light at a wavelength of $254 \mathrm{~nm}$ [40]. (Figure 5).

Nowadays, the environmental impact assessment study, along with the programme of mitigation measures, contains a water monitoring programme as its integral part. Similarly, 
assessing the status of groundwater-dependent eco-systems (EWDS) should be required in any water tapping project: the main question is the amount of water to be provided to the system to sustain the services of the ecosystem as an ecological (environmental) flow. This is not always an easy task in a dynamic karst environment, and can be done only after systematic groundwater monitoring, budgeting of water resources and possibly modelling. The number of monitored indicators can largely extend typical "water" parameters and include several different markers for the status of ecology and biodiversity [41].

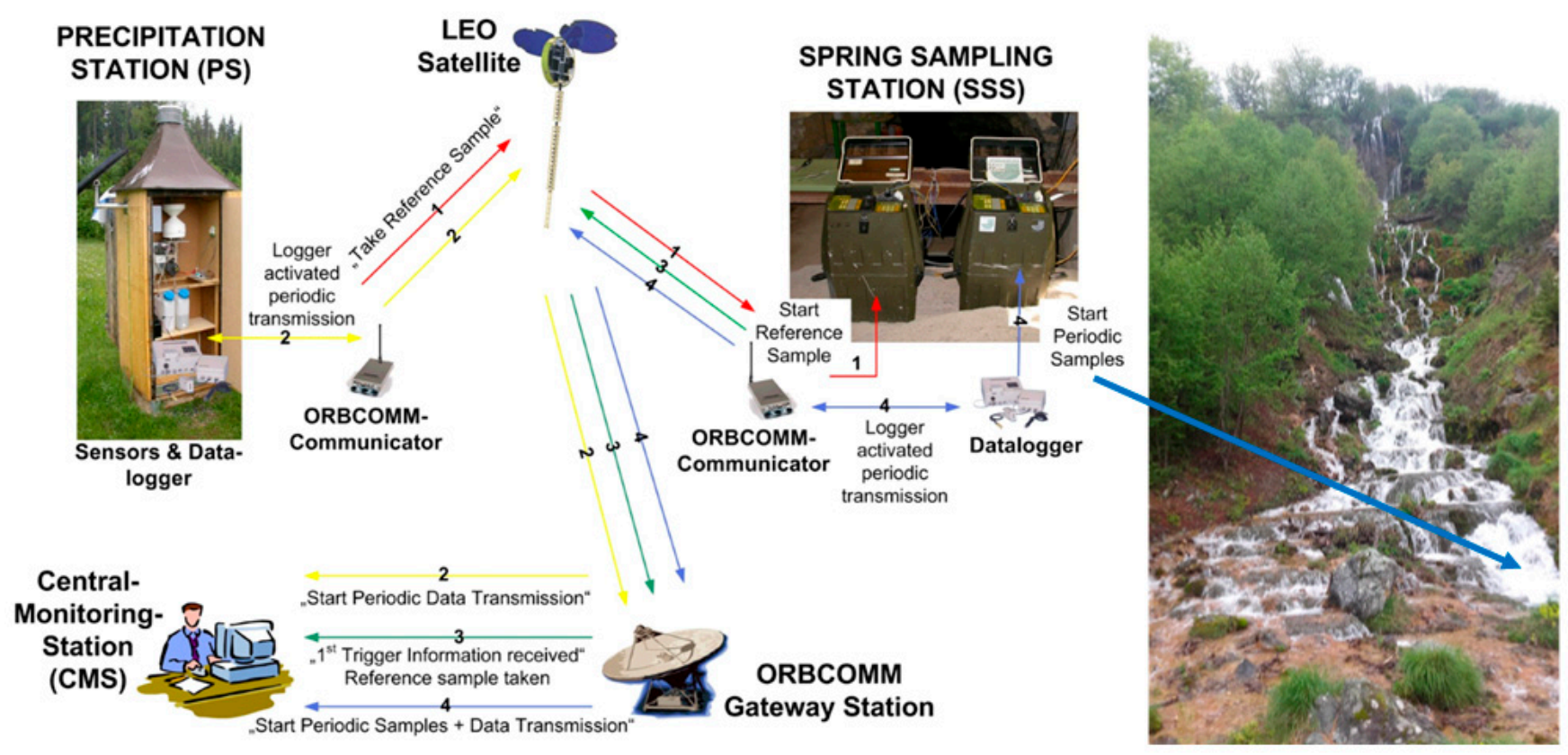

Figure 5. Example of a monitoring station for EWS. Stream of data and information of an event-triggered LEO Satellite Hydrology Network (according to Stadler et al. [39], modified).

Due to the demands of systematic monitoring in utilities responsible for potable water supply, sophisticated observation equipment is often installed at many dam sites and reservoirs. Especially when they are built in karst, these structures require special attention and engineering aimed at preventing leakage and water losses [42]. Although direct measurement of leakage is never easy, and sometimes even impossible, monitoring of the fluctuation of the water level in the reservoir and the piezometric network around it, accompanied by the auscultation of parameters of water chemistry, seismicity and aquifer pressure, may help assess the status and intensity of undesired processes.

Assessment of the impact of climate changes on water resources in karst always requires a good set of historical data. By correlating global or regional downscaled climate data to the basin scale of a specific grid, and coupling them with observed historical data on spring's discharge or water table fluctuations, it is possible to establish a stochastic model and predict future changes in groundwater resources.

\subsection{Proposed Protocols and Intervals of Monitoring in Karst}

Several papers discuss protocols and the frequency of measurements and sampling of water in karst.

Quinlan [43] states that groundwater monitoring in karst terrains can be done reliably, but that the analytical costs are likely to be significantly higher than those for other terrains due to the need for more frequent sampling. He suggests that sampling for water quality should be done before, during and after storm and meltwater events, while baseflow should be sampled between such events. In addition, tracing tests for delineation of the catchment should support the selection of monitored sites-springs, cave streams and wells. 
The choice of measurement intervals depends mainly on four conditions [44]: accessibility of the location, the equipment used for monitoring, the task and the desired results. Milanović and Vasić divide monitoring into four groups: continuous, daily, weekly and monthly [44] (p. 345):

"(a) Continual (hourly level)-monitoring of spring discharge or sinking stream capacity. Not common; used just in special cases such as before, during and after high rains,

(b) Daily-flow measurement mostly provided in karst areas. Generally provides sufficient data for further analyses.

(c) Weekly-flow measurement and water quality analysis. Mostly provided for springs with stable regimes. Not usual for chemical analyses, except in special cases,

(d) Monthly-very rare flow measurement on a monthly basis, while such intervals are very common for water quality analyses."

Due to the dynamic of karst aquifers, they generally propose that groundwater level should be monitored and recorded on a daily basis, while the quality of water should be tested bi-monthly.

\section{Discussion}

Based on previous examples, we can distinguish four main categories of groundwater monitoring networks:

1. International-the network comprises monitoring sites in two or more countries that share the aquifer system, and is created based on a bilateral or multilateral agreement;

2. National-the network does not exceed one country and generally one organisation is responsible for its management [22-29]; them;

3. Regional/local-there are several networks, and several organisations that manage

4. Project-based-the network is established as temporary, for the duration of the project implementation, but later may be handed over to the responsible authority for further operation and maintenance [30,31].

In principle, structure and elements of an international type of network are not defined in any of the many international legislative acts and documents that have been adopted and put to practice. For instance, the "Law of Transboundary Aquifers" [12] promotes, in a general manner, international cooperation between the aquifer states and, quite logically, does not discuss details such as divergencies and demands related to organising the monitoring aquifer systems.

Although the EU Water Framework Directive (WFD recognises that karst (flow) demands more frequent measurements of quantitative and qualitative parameters, its dynamic regime cannot definitely be adequately studied by the proposed four visits and by samples taken during one hydrological year [13-15]. The fact that proposed monitoring is a "minimal" requirement provides an opportunity to EU member states to adapt their approach to each specific case that may include karst GWBs.

The IGRAC's Guideline on Groundwater Monitoring for General Reference Purposes [21] is a useful document that discusses various aspects of conceptualisation, characterisation of aquifer systems and possible designing of monitoring of the quantity and quality of water. However, the aspects of specific demands of observation of karst aquifers are shortly mentioned under the topic on monitoring the water quantity in consolidated sedimentary basins.

In the last few decades, sustainable water development and demand for equitable sharing of water resources, including groundwater, have become a part of many bi- or multilateral agreements, documents, articles and projects dealing with transboundary waters. However, not many of them are dealing with the methodology to be used to achieve and define the amount of water to be equally or proportionally shared and used, or how and where to organise monitoring and prevent precious groundwater deterioration or 
pollution. These tasks are mostly left to water experts, who develop or sometime improvise approaches adapted to specific local conditions.

The international monitoring system should be agreed upon and harmonised between countries in question. The selection of observing parameters should consider a jointly prepared hydrogeological conceptual model. However, even in large international aquifer systems, where multilateral agreements on equitable water use and protection have been reached, no systematic monitoring of groundwater quantity and quality has taken place to date. One such case is the Nubian aquifer system shared among Libya, Egypt, Chad and Sudan, while the Guarani aquifer system shared among Argentina, Brazil, Paraguay and Uruguay is another [45]. The only exception is the Genevese aquifer, shared by France and Switzerland [46]. Although none of the above three is a pure "karstic" transboundary aquifer (TBA), these examples confirm the complexity and high price as major obstacles for the establishment and maintenance of groundwater monitoring networks and the creation of joint consultative bodies for sustainable water management.

An attempt to create a modern automated and remote monitoring system for transboundary karst water of the Cijevna River basin shared between Montenegro and Albania was a part of the DIKTAS project [47]. The general setup of a Monitoring Network, which is currently in its final design phase, includes the following parameters [41]: rainfall and other climate elements (air temperature, humidity, wind, evaporation) observed on a daily basis; riverflow observed by limnigraphs for automatic recording on the Cijevna River and gauging stations installed on several tributaries in both countries (in border area: entrance/exit stations); springflow observed on a permanent or daily basis by limnigraphs for automatic recording and classical gauging stations installed on major springs within TBA; groundwater table observed by automatic data logger installed in newly drilled piezometers selected to represent the aquifer system in recharge/discharge areas in both countries; the sampling frequency and the number of observed water quality parameters (salinity, chemistry, turbidity, biology, specific components and pollutants) will be once per month, while in the case of water quality deterioration, sampling should be even more frequent. A more intense monitoring than what was proposed by WFD for operational one is thus required [13-15]. In total, 21 observation points should be launched within this joint Groundwater Monitoring Network [48]. The "border station" is the most important, and it is advisable that first-year analyses be performed by accredited laboratories in both countries in order to establish a proper calibration of analytical methods. Almost all stations should be equipped with instruments for automatic discharge recording and data transmission with autonomous battery recharge.

IGRAC experts emphasise that design options of monitoring programmes may differ in [21]:

- The number of area(s) to be monitored;

- The setup of the monitoring network (discharge measuring points, observation wells or combinations thereof);

- The number of monitoring wells and vertical distribution of piezometers;

- The selected parameter sets (especially important for groundwater quality monitoring);

- The method of measuring (manual, recorders, combinations);

- The frequency of observation.

They conclude that there is an almost infinite number of possible monitoring programmes, and that the challenge is to define and work out a limited number of realistic options.

The conflict between "realistic" and "reliable" would always be present, especially in terms of a karst aquifer as a heterogenous and anisotropic medium. In fact, information obtained from one site could be irrelevant to the neighbouring one, as carbonate rocks can differ from highly karstified to purely compact and impervious regardless of the fact that they are just a few metres away from each other [7]. The representativeness of a 
monitoring site is thus essential, but also especially problematic when one considers the most expensive monitoring objects—drilled boreholes/piezometers [49].

As regards parameters of water quality to be observed in an early warning system, in addition to the standard ones proposed by WFD [13-16] we can advise the following: water turbidity, total organic carbon (TOC) [50], total coliforms, E. coli and particle size distribution [51]. The measured parameters' data in real-time monitoring should be uploaded to an online database. Based on obtained data, the appropriate algorithm would continuously assess the potential risk of contamination and automatically validate its forecasting in near-real time and give a warning about the risk of contamination for spring water quality [52].

The importance of most frequent observation of karst aquifers could be illustrated by the following two examples, one for the variation of water quantity, and the other for that of quality.

For the purpose of assessing the impact of climate changes on the regime of karst aquifers of Durmitor Mt. In Montenegro, the diver/data logger for the continual observation of the variation of discharge has been installed at the Glava Šavnika spring [53]. Figure 6 shows how an aquifer's behaviour can be estimated if fluctuations are recorded continuously over a period of 6 months and if measurements (by reading the installed gauge) are taken at the intervals of 5 and 15 days. If we simply compare the registered amplitudes, the situation is the following (Table 1):

Table 1. Recorded amplitudes of the Glava Šavnika spring, by means of various intervals of measurement.

\begin{tabular}{ccc}
\hline Method & Minimum (1/s) & Maximum (1/s) \\
\hline Continuous records & 90 & 1150 \\
\hline 5-day measurements & 180 & 1080 \\
\hline 15-day measurements & 270 & 960 \\
\hline
\end{tabular}

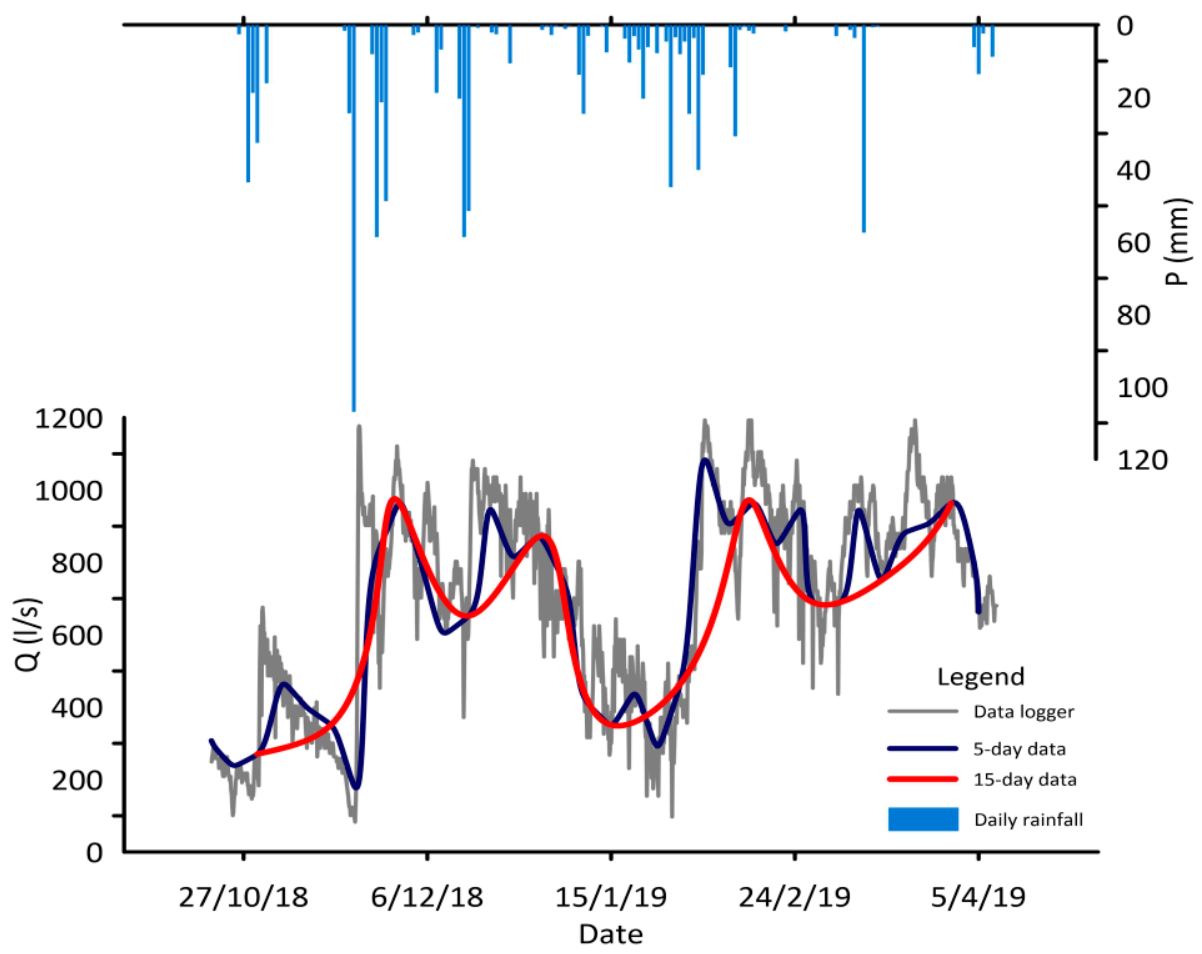

Figure 6. Observations of the Glava Šavnika karst spring, recorded continually and with 5-day and 15-day intervals. 
This is a typical example of the importance of more frequent and continual recording of groundwater fluctuation. If, for instance, water managers organise just sporadic measurement (every 15 days) of discharge of a spring proposed to be tapped out for water supply, they will show a minimal value that is three times higher than the accurate one, which may have negative consequences on securing water not only for future water consumers, but even more for the dependent ecosystem.

Stadler $\mathrm{H}$. organised frequent measurements of the conductivity value of one karstic spring in the Austrian High Alps during the one month period of snow melting [39,40]. Figure 7 shows spring water conductivity by recorded intervals of: 15 min, daily, weekly, bi-weekly, monthly and quarterly. As in the previous explained case, the amplitudes obtained by different measurement intervals show an enormous variety. By comparing the values recorded just by the two extreme frequencies of $15 \mathrm{~min}$ and monthly intervals, we can note highly variable amplitudes, $169-238 \mu \mathrm{S} / \mathrm{cm}$ in the former, and $205-223 \mu \mathrm{S} / \mathrm{cm}$ in the latter case.

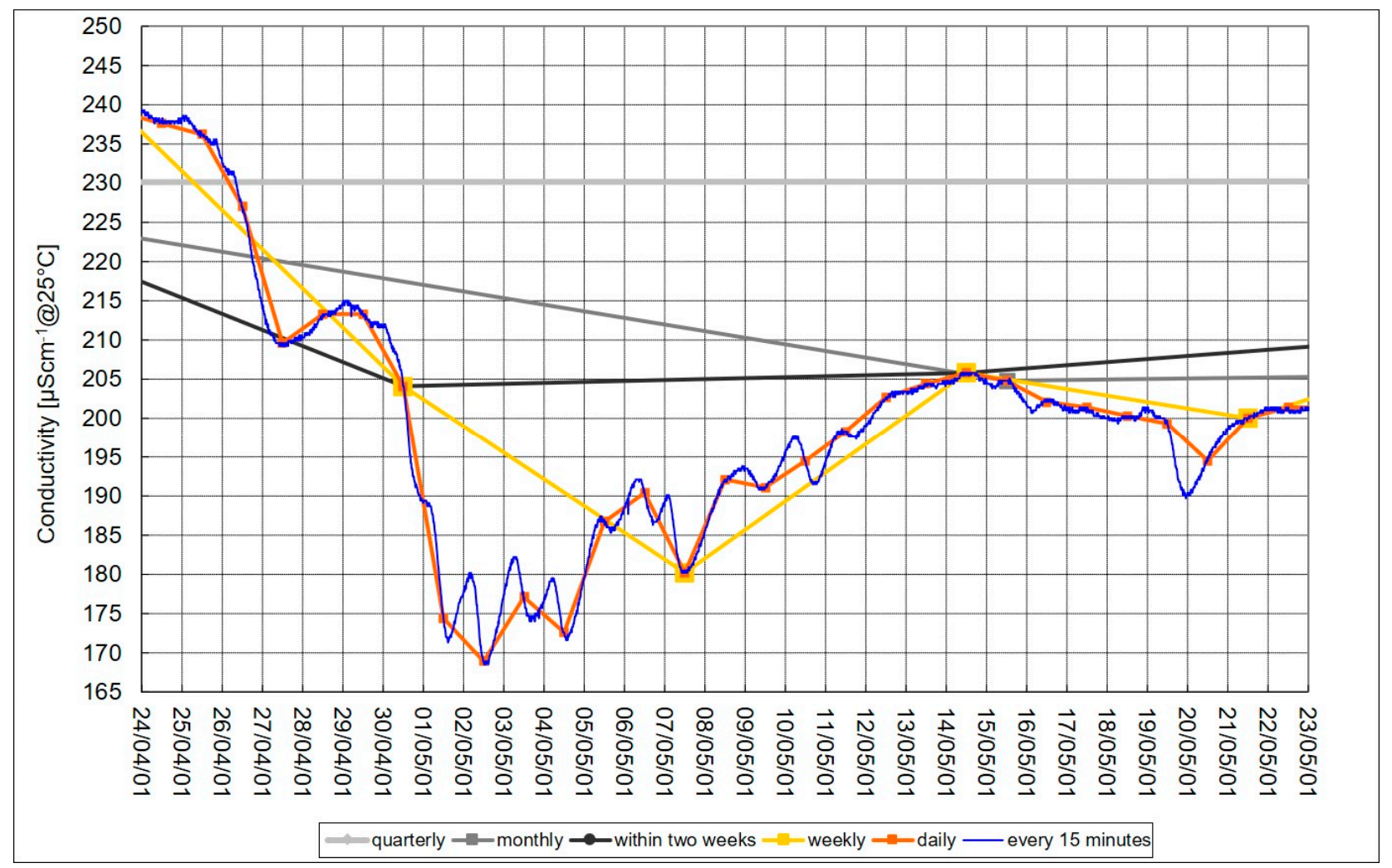

Figure 7. Observations of a karst spring in the High Alps during snowmelt. Measurements conducted in intervals ranging from 15 min to quarterly (figure courtesy of Hermann Stadler).

\section{Conclusions}

Due to its heterogeneity and anisotropy, as well as the high level of porosity and cavernosity, a karst aquifer is a specific medium, more dynamic than any other aquifer system. Moreover, such aquifers are dominantly characterised by a turbulent flow and high vulnerability to pollution.

Although groundwater resources are, and will continue to be, increasingly exposed to pressures that affect quantity and quality, karstic aquifers are especially sensitive to natural and anthropogenic changes in the environment. Because of this natural behaviour of karst, the climate change and specially prolonged droughts have significant impact on reduced recharge and groundwater availability. The establishment and maintenance of monitoring networks is necessary to prevent depletion of groundwater reserves and deterioration of their quality. The actions to improve monitoring may be carried out in the three levels: 
global, national and project-based. WOKAM as one of very first steps in international recognition of karst aquifers distribution created a base for further projects, which among others may include proposal for global network or specific projects to monitor selected springs such as WOKAS.

IRGAC is actually a single organisation that has initiated the groundwater global network, GGMN. Support of UNESCO-IHP or Karst Commission of IAH may facilitate its further development and extension to monitor specific aquifers as karstic ones.

Although national groundwater networks at global scale rarely recognised differences between aquifer systems and needs for various frequency of their observation, some initial steps have been made in EU documents by recognition of karst as a "special case". However, for the proper assessment of dynamics of designated karst aquifers, continual observation of quantitative and selected qualitative elements of their regime is required. A few presented case examples in this overview explain why permanent monitoring is necessary, be it continual or as frequent as possible.

Some karst aquifers need even more attention and frequent monitoring, if continual is not possible. Those are: sources tapped for centralised potable water supply; aquifers with confirmed over-extraction and considerable water table depletion; transboundary aquifers; aquifers in arid areas, in certified vulnerable zones, and in densely populated areas; coastal aquifers; and aquifers with proven connection with active ponors or surface waters.

Although the feasibility of a monitoring programme depends, among other things, on available budgets and institutional capacities, only systematically collected and properly evaluated data can provide a base for sustainable water management and possible corrective measures at the regional (aquifer systems) or local (source) level.

Author Contributions: Methodology, Z.S.; data collection and validation, Z.S., A.M.S.; data analysis, Z.S., A.M.S.; writing—original draft preparation, Z.S.; writing-review and editing, Z.S., A.M.S.; visualisation, A.M.S., Z.S. All authors have read and agreed to the published version of the manuscript.

Funding: This research received no external funding.

Acknowledgments: This article is dedicated to Hermann Stadler, the Austrian senior hydrologist and groundwater expert who organised and conducted the continual observation of chemical and microbiological quality of spring water in the High Alpine mountains. He passed away in late 2016, due to the infection caused by a malicious pathogen he probably encountered during his field work. The authors gratefully acknowledge data provided by the courtesy of our dear colleague and great friend Hermann. The authors also acknowledge the administrative support to Project 176022 provided by the Ministry of Science and Technological Development of Serbia.

Conflicts of Interest: The authors declare no conflict of interest.

\section{References}

1. Zektser, I.S.; Everett, L.G. Groundwater Resources of the World and Their Use. 2004. Available online: https://hydrologie.org/ BIB/Publ_UNESCO/SOG6.pdf (accessed on 5 May 2021).

2. Margat, J.; van der Gun, J. Groundwater around the World: A Geographic Synopsis; CRC Press: Boca Raton, FL, USA, 2013 ; p. 348.

3. Goldscheider, N.; Zhao, C.; Auler, A.; Bakalowicz, M.; Broda, S.; Drew, D.; Hartmann, J.; Jiang, G.; Moosdorf, N.; Stevanović, Z.; et al. Global distribution of carbonate rocks and karst water resources. Hydrogeol. J. 2020. [CrossRef]

4. Stevanović, Z. Karst waters in potable water supply: A global scale overview. Environ. Earth Sci. 2019, 78, 1-12. [CrossRef]

5. Milanović, P. Karst Hydrogeology; Water Resources Publication: Littleton, CO, USA, 1981.

6. Kresic, N. Water in Karst. Management, Vulnerability and Restoration; McGraw Hill: New York, NY, USA, 2013.

7. Stevanović, Z. Characterization of karst aquifer. In Karst Aquifers-Characterization and Engineering; Stevanović, Z., Ed.; Springer International Publishing: Cham, Switzerland, 2015; pp. 47-126. [CrossRef]

8. Käss, W. Tracing Technique in Geohydrology (English Translated of Geohydrologische Markierungstechnik); Balkema: Rotterdam, The Netherlands, 1998; p. 581.

9. Benischke, R.; Goldscheider, N.; Smart, C.C. Tracer techniques. In Methods in Karst Hydrogeology; Goldscheider, N., Drew, D., Eds.; Taylor \& Francis: London, UK, 2007; pp. 147-170.

10. Aller, L.; Bennet, T.; Lehr, J.; Petty, R.; Hackett, G. DRASTIC: A Standardized System for Evaluating Ground Water Pollution Potential Using Hydrogeologic Settings; EPA: Chicago, IL, USA, 1987. 
11. Dörfliger, N.; Zwahlen, F. EPIK: A new method for outlining of protection areas in karstic environment. In Karst Water and Environmental Impacts; Günay, G., Johnson, I., Eds.; Balkema: Rotterdam, The Netherlands, 1997; pp. 117-123.

12. United Nations General Assembly. Law on Transboundary Aquifers, (Resolution 63/124). The International Law Commission. New York. 2008. Available online: https://legal.un.org/ilc/texts/instruments/english/draft_articles/8_5_2008.pdf (accessed on 16 August 2020).

13. European Commission. 2000: Water Framework Directive WFD 2000/60. Available online: http://www.worldlibrary.in/articles/ eng/Water_Framework_Directive (accessed on 5 May 2021).

14. European Commission. 2006: Directive 2006/118/EC of the European Parliament and of the Council of 12 December 2006 on the Protection of Groundwater against Pollution and Deterioration; Official Journal of the EU: Brussels, Belgium, 2006.

15. European Commission. Common Implementation Strategy for the Water Framework Directive (2000/60/EC). Guidance Document No. 7, Monitoring under the Water Framework Directive; European Commission: Brussels, Belgium, 2007.

16. European Commission. Common Implementation Strategy for the Water Framework Directive (2000/60/EC). Guidance Document No. 15, Guidance on Groundwater Monitoring; European Commission: Brussels, Belgium, 2007.

17. Olarinoye, T.; Gleeson, T.; Marx, V.; Seeger, S.; Adinehvand, R.; Allocca, V.; Andreo, B.; Apaéstegui, J.; Apolit, C.; Arfib, B.; et al. Global karst springs hydrograph dataset for research and management of the world's fastest-flowing groundwater. Sci. Data 2020, 7, 254. [CrossRef] [PubMed]

18. Cvijić, J. Das Karstphänomen. Versuch einer morphologischen Monographie; Geographischen Abhandlung: Wien, Austria, 1893; Volume 3, pp. 218-329.

19. UNESCO-IHP. Available online: https://en.unesco.org/themes/water-security/hydrology/groundwater (accessed on 26 December 2020).

20. IGRAC. Available online: https:/ / www.un-igrac.org/ (accessed on 26 December 2020).

21. IGRAC. Guideline on: Groundwater Monitoring for General Reference Purposes; Jousma, G., Ed.; Report nr. GP 2008-1; IGRAC: Utrecht, The Netherlands, 2008; p. 165.

22. IGRAC. Groundwater Monitoring Programmes: A Global Overview of Quantitative Groundwater Monitoring Networks; Ruz Vargas, C., Kukuric, N., Eds.; IGRAC: Delft, The Netherlands, 2020; p. 144.

23. IGWWG (Ireland GW Working Group). 2005: WFD- River Basin District Management Systems, Advice on the Implementation of Guidance on Monitoring Groundwater; Guidance Document No. GW6; IGWWG: Dublin, Ireland, 2005.

24. USGS-National Ground-Water Monitoring Network. Available online: https://cida.usgs.gov/ngwmn/index.jsp (accessed on 28 December 2020).

25. Benischke, R. Karst water resources of Austria, hydrogeological aspects and problems. In Proceedings of the Karst 2018 Expect the Unexpected, Trebinje, Bosnia and Herzegovina, 6-9 June 2018; pp. 23-29.

26. Federal Ministry of Agriculture, Regions and Tourism of the Republic of Austria. Available online: https://www.bmlrt.gv.at/ wasser/wasser-oesterreich/grundwasser.html (accessed on 20 December 2020).

27. Report on Monitoring (in Slovenian) 2019: Quantitative Status of Groundwater in Slovenia; Ministry of Environment and Spatial Planning of Slovenia: Ljubljana, Slovenian, 2019; p. 103.

28. Croatian Meteorological and Hydrological Service. Available online: https://meteo.hr/infrastruktura_e.php?section=mreze_ postaja\&param $=h m \& e l=$ povrsinske_hm (accessed on 21 December 2020).

29. Stevanović, Z.; Marinović, V. A methodology for assessing the pressures on transboundary groundwater quantity and quality -Experiences from the Dinaric karst. Geol. Croat. 2020, 73, 107-118. [CrossRef]

30. Stevanovic, Z.; Iurkiewicz, A. Hydrogeology of Northern Iraq. In Regional Hydrogeology and Aquifer Systems; FAO: Rome, Italy, 2004; Volume 2, p. 175.

31. Balint, Z.; Stevanović, Z.; Gadain, H.; Milanović, S.; Trivić, B.; Marobhe, I. Hydrogeological Survey and Assessment of Selected Areas in Somaliland and Puntland. 2012. Available online: https://scholar.google.com.hk/scholar?hl=zh-CN\&as_sdt=0\%2C5 $\& q=$ Hydrogeological+survey+and+assessment+of+selected+areas+in+Somaliland+and+Puntland\&btnG= (accessed on $5 \mathrm{May}$ 2021).

32. Bakalowicz, M. Karst groundwater: A challenge for new resources. Hydrogeol. J. 2005, 13, 148-160. [CrossRef]

33. Blavoux, B.; Mudry, J.; Puig, J.M. The karst system of the Fontaine de Vaucluse (Southeastern France). Environ. Geol. Water Sci. 1992, 19, 215-225. [CrossRef]

34. Bonacci, O. Analysis of long-term (1878-2004) mean annual discharges of the karst spring Fontaine de Vaucluse (France). Acta Carsologica 2007, 36, 151-156. [CrossRef]

35. Bonacci, O. Karst Hydrology with Special Reference to the Dinaric Karst; Springer: Berlin, Germany, 1987.

36. Tapley, B.D.; Bettadpur, S.; Watkins, M.; Reigber, C. The gravity recovery and climate experiment: Mission overview and early results. Geophys. Res. Lett. 2004, 31, L09607. [CrossRef]

37. Hartmann, A.; Liu, Y.; Olarinoye, T.; Berthelin, R.; Marx, V. Integrating field work and large-scale modeling to improve assessment of karst water resources. Hydrogeol. J. 2021, 29, 315-329. [CrossRef]

38. Stevanović, Z. Utilization and regulation of springs. In Groundwater Hydrology of Springs: Engineering, Theory, Management and Sustainability; Kresic, N., Stevanovic, Z., Eds.; Burlington: Oxford, UK, 2009; pp. 339-388. 
39. Stadler, H.; Clock, E.; Leis, A.; Skritek, P.; Zerobin, W.; Farnleiter, A. Event based monitoring and early warning system for groundwater resources in alpine karst aquifers. In Extended Abstracts of XXXVIII IAH Congress "Groundwater Quality Sustainability"; CRC Press: Krakow, Poland, 2010; pp. 1547-1553.

40. Stadler, H. Presentation at CEKA Course, Trebinje and Personal Communication. In Joanneum Research E Interuniversity Cooperation Centre Water E Health, Graz, Austria; Quality Dynamics at Karst Springs. A Challenge for drinking Water Supplies. Automated Microbial Sampling at Event-Scale; CEKA Course: Trebinje, Bosnia Herzegovina, 2016.

41. Stevanović, Z. Creating environmental impact indicators in dynamic karst system—Dinaric karst case example. In Karst Without Boundaries; Stevanović, Z., Kresic, N., Kukuric, N., Eds.; CRC Press/Balkema: Boca Raton, FL, USA; Taylor \& Francis Group: London, UK, 2016; pp. 287-310.

42. Milanović, P. Water Resources Engineering in Karst; CRC Press: Boca Raton, FL, USA, 1984.

43. Quinlan, F.J. Ground-Water Monitoring In Karst Terranes Recommended Protocols and Implicit Assumptions; Environmental Monitoring System Laboratory: Las Vegas, NV, USA, 1989; p. 79.

44. Milanović, S.; Vasić, L.J. Monitoring of karst groundwater. In Karst Aquifers-Characterization and Engineering; Stevanović, Z., Ed.; Springer International Publishing: Cham, Switzerland, 2015; pp. 47-126. Available online: https://link.springer.com/chapter/10 .1007/978-3-319-12850-4_12 (accessed on 5 May 2021).

45. Valente, M. MERCOSUR Vows to take over Huge Water Reserve, Mercosur Article; Inter Press Service (IPS): Rome, Italy, 2002.

46. Wohlwend, J.B. An Overview of Groundwater in International Law-A Case Study: The Franco-Swiss Genevese Aquifer. 2002. Available online: https:/ / scholar.google.com.hk/scholar?hl=zh-CN\&as_sdt=0\%2C5\&q=An+overview+of+groundwater+in+ international+law\%E2\%80\%94A+case+study\%3A+The+Franco-Swiss+Genevese+Aquifer\&btnG= (accessed on $5 \mathrm{May} 2021)$.

47. Stevanović, Z.; Kukurić, N.; Pekaš, Ž.; Jolović, B.; Pambuku, A.; Radojević, D. Dinaric Karst Aquifer-One of the world's largest transboundary systems and an ideal location for applying innovative and integrated water management. In Karst without Boundaries; Stevanović, Z., Kresic, N., Kukuric, N., Eds.; CRC Press/Balkema: Boca Raton, FL, USA; Taylor \& Francis Group: London, UK, 2016; pp. 3-25.

48. Blagojević, M.; Stevanović, Z.; Radulović, M.; Marinović, V.; Petrović, B. Transboundary groundwater resource management: Needs for monitoring the Cijevna River Basin (Montenegro-Albania). Environ. Earth Sci. 2020, 79, 74. [CrossRef]

49. Toomey, R.S. Geological monitoring of caves and associated landscapes. In Geological Monitoring; Young, R., Norby, L., Eds.; Geological Society of America: Boulder, CO, USA, 2009; pp. 27-46.

50. Frank, S.; Goeppert, N.; Goldscheider, N. Fluorescence-based multi-parameter approach to characterize dynamics of organic carbon, faecal bacteria and particles at alpine karst springs. Sci. Total Environ. 2018, 615, 1446-1459. [CrossRef] [PubMed]

51. Goeppert, N.; Goldscheider, N. Improved understanding of particle transport in karst groundwater using natural sediments as tracers. Water Res. 2019, 166, 115045. [CrossRef] [PubMed]

52. Marín, I.A.; Rodríguez, F.M.J.; Barberá, A.J.; Fernández-Ortega, J.; Mudarra, M.; Sánchez, D.; Andreo, B. Groundwater vulnerability to pollution in karst aquifers, considering key challenges and considerations: Application to the Ubrique springs in southern Spain. Hydrogeol. J. 2021, 29, 379-396. [CrossRef]

53. Stevanović, Z.; Petrović, B.; Marinović, V.; Radojević, D.; Samolov, V. Geology and hydrogeology of studied Šavnik/Durmitor area. In Hydrogeology and Climate Changes Impact on Aquifer Systems of Drina River Basin; Stevanović, Z., Blagojević, M., Eds.; Ministry of Agriculture, Forestry and Water Management of Montenegro: Podgorica, Montenegro, 2021, in press. 